\title{
Assessing reduction of cluster size to estimate wood volume in an Amazonian forest
}

\author{
Nivea Maria Mafra RODRIGUES ${ }^{*} \mathbb{\oplus}$, Hassan Camil DAVID², Gabriel William Dias FERREIRA ${ }^{3}$, Emanuel \\ José Gomes ARAÚJO4, Vinícius Augusto MORAIS5 \\ 'Universidade Federal do Espírito Santo - UFES, Departamento de Ciências Florestais e da Madeira, Av. Governador Lindemberg, 29550-000, Jerônimo Monteiro, ES, \\ Brazil \\ 2 Universidade Federal Rural da Amazônia - UFRA, Av. Pau Amarelo, 68650-000, Capitão Poço, PA, Brazil \\ 3 Universidade Federal de Lavras - UFLA, Departamento de Ciências Florestais, Campus UFLA, CP 3037, 37200-000, Lavras, MG, Brazil \\ ${ }^{4}$ Universidade Federal Rural do Rio de Janeiro - UFRRJ, Departamento de Silvicultura, rodovia 465, km 07, 23890-000, Seropédica, RJ, Brazil \\ 5 Universidade do Estado de Mato Grosso - UNEMAT, Av. Perimetral Deputado Rogério Silva, CP 324, 78580-000, Alta Floresta, MT, Brazil \\ * Corresponding author: niveamafra11@gmail.com; (D) https://orcid.org/0000-0002-3750-0813
}

\begin{abstract}
While the Brazilian National Forest Inventory (NFI) is in progress, there is a growing demand to understand the effect of cluster size on the accuracy and precision of forest-attribute estimation. We aimed to find the minimum cluster size (in area) to estimate merchantable volume (MV) with the same accuracy and precision as the estimates derived from the original cluster of $8,000 \mathrm{~m}^{2}$. We used data from an inventory carried out in a forest unit (Bom Futuro National Forest) in the southwestern Brazilian Amazon, where 22 clusters were distributed as a two-stage sampling design. Three products were evaluated: (i) MV of trees with a diameter at breast height $(\mathrm{DBH}) \geq 20 \mathrm{~cm}(\mathrm{P} 1)$; (ii) $\mathrm{MV}$ of trees with $\mathrm{DBH} \geq 50 \mathrm{~cm}$ (P2); and (iii) MV of commercial species with $\mathrm{DBH} \geq 50 \mathrm{~cm}$ and stem quality 'level 1' or 'level 2' (P3). We assessed ten scenarios in which the cluster size was reduced from $8,000 \mathrm{~m}^{2}$ to $800 \mathrm{~m}^{2}$. The accuracy of P1, P2 and P3 was highly significantly lower for reductions $<2,400 \mathrm{~m}^{2}$. The precision was more sensitive to variations in cluster size, especially for P2 and P3. Minimum cluster sizes were $\geq 2,400 \mathrm{~m}^{2}$ to estimate $\mathrm{P} 1, \geq 4,800 \mathrm{~m}^{2}$ to estimate $\mathrm{P} 2$, and $\geq 7,200 \mathrm{~m}^{2}$ to estimate $\mathrm{P} 3$. We concluded that it is possible to reduce the cluster size without losing the accuracy and precision given by the original NFI cluster. A cluster of $2,400 \mathrm{~m}^{2}$ provides estimates as accurate as the original cluster, regardless of the evaluated product.
\end{abstract}

KEYWORDS: National Forest Inventory, merchantable volume, precision, accuracy, Amazonian timber species

\section{Avaliando a redução do tamanho do conglomerado para estimar o volume de madeira em uma floresta amazônica}

\section{RESUMO}

Enquanto o Inventário Florestal Nacional Brasileiro (IFN) está em andamento, há uma demanda crescente para entender o efeito da área do conglomerado sobre a exatidão e precisão da estimativa de atributos florestais. O objetivo deste estudo foi determinar a área mínima de um conglomerado para estimar o volume comercial (VC) com a mesma acurácia e precisão que as estimativas derivadas do conglomerado original de $8.000 \mathrm{~m}^{2}$. A base de dados é proveniente de um inventário realizado em uma unidade florestal (Floresta Nacional do Bom Futuro) no sudoeste da Amazônia brasileira, onde 22 conglomerados foram distribuídos em um desenho amostral em dois estágios. Foram avaliados três produtos: (i) VC de árvores com diâmetro à altura do peito (DAP) $\geq 20 \mathrm{~cm}$ (P1); (ii) VC de árvores com DAP $\geq 50 \mathrm{~cm}$ (P2); e (iii) VC de espécies comerciais com DAP $\geq 50$ cm e qualidade de fuste 'nível 1' ou 'nível 2' (P3). O estudo avaliou dez cenários em que a área do conglomerado foi reduzida de 8.000 a $800 \mathrm{~m}^{2}$. A acurácia de P1, P2 e P3 foi significativamente menor para reduçóes $<2.400 \mathrm{~m}^{2}$. A precisão foi mais sensível à variação no tamanho do conglomerado, sobretudo para P2 e P3. Os tamanhos mínimos de conglomerado foram $\geq$ $2.400 \mathrm{~m}^{2}$ para estimar $\mathrm{P} 1, \geq 4.800 \mathrm{~m}^{2}$ para estimar $\mathrm{P} 2 \mathrm{e} \geq 7.200 \mathrm{~m}^{2}$ para estimar P3. Concluímos que é possível reduzir a área do conglomerado sem perder acurácia e precisão do conglomerado original do IFN. Um conglomerado de $2.400 \mathrm{~m}^{2}$ fornece estimativas com a mesma acurácia que o conglomerado original, independentemente do produto avaliado.

PALAVRAS-CHAVE: Inventário Florestal Nacional, volume comercial, precisão, acurácia, espécies madeireiras amazônicas 


\section{INTRODUCTION}

Forest inventories are the main tool to quantify and characterize forest resources and their composition, providing useful information to forest management, conservation, and policy (Tomppo et al. 2010). Based on the degree of coverage, the inventories can be classified either as complete, when the entire forest is measured (i.e., a census), or incomplete, when only a forest sample is evaluated (Loetsch et al. 1973). In the latter case, a representative sample is crucial, which depends on distinct factors, such as the dimension of sampling units and the sampling design, which define the precision of estimates.

Increasing forest inventory efficiency is a trade-off between attaining higher accuracy and precision, and seeking practices that allow cost reduction (Westfall et al. 2011; Westfall et al. 2016; Räty et al. 2018). In general, costs are directly related to data detail level and sampling intensity (Druszcz et al. 2012), as well as sampling unit area (Westfall et al. 2016). Plot area rules the precision and accuracy of estimates of forest attributes, while precision is also dependent on available resources, as field assessments generally are a demanding component of the forest inventory (Westfall et al. 2016; Räty et al. 2018; Westfall et al. 2019). Therefore, defining minimal sampling effort that ensures both high accuracy and precision in the estimation of variables of interest will increase inventory efficiency (Gregoire and Valentine, 2007; Westfall et al. 2016).

The challenge of finding the optimal trade-off between precision/accuracy and sampling effort is intensified in the Brazilian National Forest Inventories (NFIs). The NFI is one of the main surveys carried out by the federal government to produce information on Brazilian forest resources (SFB 2020). In the NFI, the ratio between sampled area and population area is notably smaller than in small-scale inventories. NFI SUs usually are field plots structured as clusters of smaller sub-units (Lawrence et al. 2010). These SUs are systematically distributed across the national territory (Westfall et al. 2016). The Brazilian NFI SUs usually are clusters of 4,000 or 8,000 $\mathrm{m}^{2}$. The preference for clusters is, among other reasons, the lower variation among clusters, thus requiring the use of fewer SUs (Cochran 1977).

There is a growing demand to understand the relationship of cluster size with accuracy and precision of estimates, i.e., what is the effect of sampling unit size on the precision and accuracy of the estimates of merchantable volume? We aimed to estimate the minimum sampling unit size that provides merchantable volume estimates as accurate and precise as the standard NFI sampling unit of $8,000 \mathrm{~m}^{2}$ used in the Amazon.

\section{MATERIAL AND METHODS}

\section{Study area}

The study area covers about $80 \%(82,918.33$ ha) of the Bom Futuro National Forest (9²7’39.0”S, 635’26.4”W), a protected area of native forest partially open for sustainable use, located between the municipalities of Porto Velho and Buritis in the state of Rondônia, Brazil (Wikiparques 2019) (Figure 1). The region has a mean annual precipitation of $2,400 \mathrm{~mm}$ and a mean temperature of $25.2^{\circ} \mathrm{C}$. According to the Köppen climate classification, the local climate is Am humid (Alvares et al. 2013).

The Bom Futuro National Forest consists of five types of vegetation formations: (i) dense alluvial rainforest (floodplain forest); (ii) dense submontane rainforest; (iii) open ombrophilous forest; (iv) savanna (forested savanna, tree savanna with gallery forest and park savanna with gallery forest); and (v) savanna/rainforest transition. The management area, composed of native forests with economic potential for sustainable management, is predominantly dominated by open forest and dense forest (ICMBio 2019). Both forest types correspond to the predominant typologies in the Amazon Biome (dense rainforest $=41.67 \%$, open rainforest $=20.91 \%$ ) (MMA 2004).

\section{Forest inventory and sampling design}

Installation of sampling units (SUs) and data collection were performed following the Brazilian NFI guidance, defined by the Brazilian Forestry Service (SFB 2019). The NFI SUs are clusters composed of four crosswise sub-units (as a Maltese cross). Each cluster had $8,000 \mathrm{~m}^{2}$, divided into four sub-units of $20 \mathrm{~m} \times 100 \mathrm{~m}\left(2,000 \mathrm{~m}^{2}\right)$, which is the standard for the Amazon biome. Further details can be found in the NFI manual (SFB 2014).

The sampling design was of two stages. The first was a systematic distribution of points $2.5 \mathrm{~km}$ apart from each other, forming a regular grid where each point represented a cell of $6.25 \mathrm{~km}^{2}(2.5 \times 2.5 \mathrm{~km})$. These $6.25-\mathrm{km}^{2}$ cells correspond to the fourth level of density of the NFI [the first level is $400 \mathrm{~km}^{2}(20 \times 20 \mathrm{~km})$, the second $100 \mathrm{~km}^{2}(10 \times 10 \mathrm{~km})$, and the third $25 \mathrm{~km}^{2}$ (5 x $5 \mathrm{~km}$ ] (Vibrans et al. 2010). The

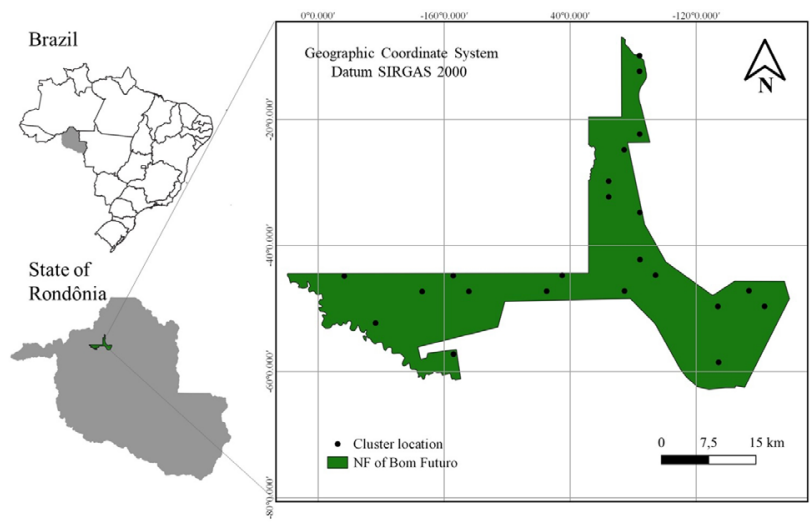

Figure 1. Location of the study area (Bom Futuro National Forest) in the state of Rondônia, Brazil, and the distribution of the 22 sampling clusters within the study area.This figure is in color in the electronic version. 
second stage was a random selection of 22 first-stage points to install 22 clusters. The number of clusters was based on a pilot inventory to meet a maximum error of $20 \%$ while estimating merchantable volume (MV) of individuals with diameter at breast heigt $(\mathrm{DBH}) \geq 20 \mathrm{~cm}$.

Each standard sub-unit was subdivided into 20 sub-plots of $10 \mathrm{~m} \times 10 \mathrm{~m}\left(100 \mathrm{~m}^{2}\right)$ (Figure 2). To assess how MV estimates change with decreasing $\mathrm{SU}$ area, we performed a stepwise reduction in the $S U$ area by eliminating the last two sub-plots of each sub-unit. Because each SU consists of four sub-units, eight sub-plots (or $800 \mathrm{~m}^{2}$ ) of each SU were removed per reduction. After these successive reductions, the SU areas were: $8,000 \mathrm{~m}^{2}$ (original area); 7,200 $\mathrm{m}^{2}$ (first reduction); 6,400 $\mathrm{m}^{2}$ (second); 5,600 $\mathrm{m}^{2}$ (third); and so on, until the ninth reduction, i.e., $800 \mathrm{~m}^{2}$, which was the smallest area. Since there were nine area reductions plus the original area, our sampling design comprised ten sampling-area sizes (Figure 2, Table 1).

\section{Wood products}

MV was our variable of interest, defined as the wood volume until either the first stem bifurcation or the beginning of a tortuosity or of the tree crown. Equation 1 was used to obtain the individual MV of the trees. This equation comes from the Schumacher-Hall linear model adjusted to the sustainable forest management plan of the Jamari National Forest, located in northeastern Rondônia state and with a similar forest type to that in the Bom Futuro National Forest.

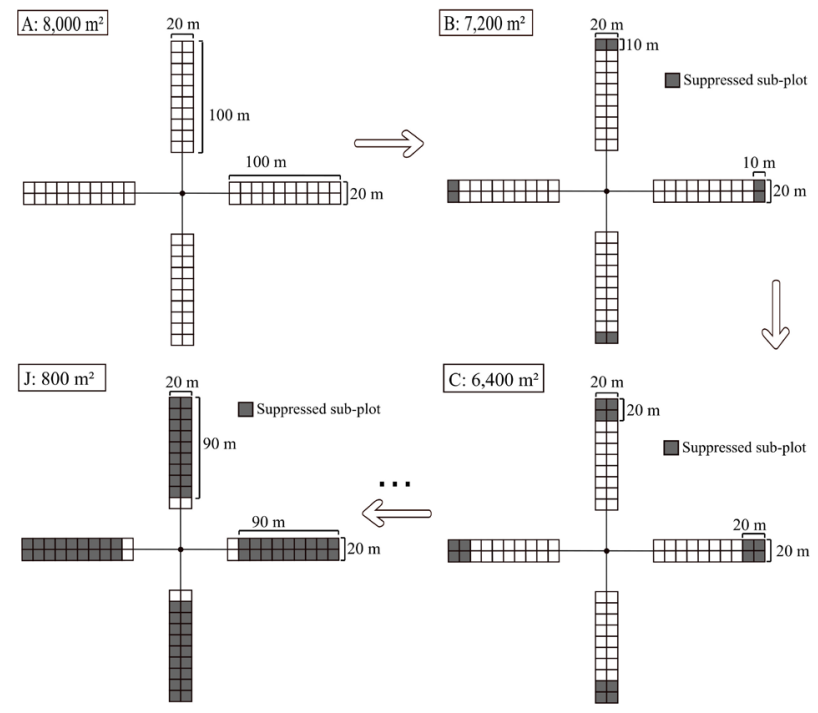

Figure 2. Diagrams of the sampling design for evaluation of the effect of cluster size on the accuracy and precision of merchantable wood volume estimation in the Bom Futuro National Forest, Rondônia state, Brazil. A - SU with standard dimension of $8,000 \mathrm{~m}^{2} ; \mathrm{B}$ - first level of area reduction to a 7,200- $\mathrm{m}^{2}$ sampling unit; $\mathrm{C}$ - second level of area reduction to $6,400 \mathrm{~m}^{2} ; \mathrm{J}$ - ninth and maximum level of tested area reduction to a $800-\mathrm{m}^{2}$ sampling unit. $\log (\mathrm{MV})=-3.81800+1.92553 \log (\mathrm{DBH})+0.66726 \log (\mathrm{HC})[1]$

where: $\mathrm{DBH}=$ diameter at breast height; $\mathrm{HC}=$ commercial height.

Source: <https://florestal.gov.br/documentos/concessoesflorestais/concessoes-florestais-florestas-sob-concessao/ flona-do-jamari/producao-2/amata/execucao-tecnica-2/163amata-poa-1/file>.

After estimating individual tree MV, three products (P1, P2 and P3) were assessed. P1 consists of MV of trees with $\mathrm{DBH} \geq 20 \mathrm{~cm} ; \mathrm{P} 2$ is $\mathrm{MV}$ of trees with $\mathrm{DBH} \geq 50 \mathrm{~cm}$; and P3 is MV of commercial species with $\mathrm{DBH} \geq 50 \mathrm{~cm}$ and stem quality 'level 1' (high stem straightness, cylindrical stem, without apparent defects) or 'level 2' (moderate stem straightness, cylindrical stem, and with acceptable defects) (see Table 2 for product statistics for $8,000-\mathrm{m}^{2} \mathrm{SUs}$ ).

\section{Precision and accuracy}

We calculated MV $\left(\mathrm{m}^{3} \mathrm{ha}^{-1}\right)$ of the products per scenario (Figure 2; Table 1; Table 2). We assumed the $8,000-\mathrm{m}^{2} \mathrm{SU}$ as the benchmark for the MV estimates. The accuracy of each other scenario (Table 1) was evaluated by comparing their MV means to the means of scenario A in the 22 replicates through Student's t-tests $(\alpha=0.05)$. The normality of the distribution of MV estimates $(\alpha=0.05)$ was assessed and confirmed by Kolmogorov-Smirnov tests. The 95\% confidence interval $(95 \% \mathrm{CI})$ of the mean was calculated for all scenarios and products.

The precision of the MV estimates for 800 to $7,200 \mathrm{~m}^{2}$ relative to $8,000 \mathrm{~m}^{2}$ was assessed through the coefficient of variation $(\mathrm{CV})$ and the sampling error for each product in the 22 cluster replicates. The sampling error was expressed as the absolute error $\left(\mathrm{E}_{\mathrm{a}}\right)$ (Equation 2) and relative error $\left(\mathrm{E}_{\mathrm{r}}\right)$ (Equation 3).

Table 1. Sampling parameters of different sampling-unit sizes for evaluation of the effect of cluster size on the accuracy and precision of the estimation of merchantable wood volume in the Bom Futuro National Forest, Rondônia state, Brazil.

\begin{tabular}{ccccc}
\hline Scenario & $\begin{array}{c}\text { SU (cluster) } \\
\text { area } \\
\left(\mathrm{m}^{2}\right)\end{array}$ & $\begin{array}{c}\text { Sampled } \\
\text { area } \\
(\mathrm{ha})\end{array}$ & $\begin{array}{c}\text { Sampling } \\
\text { intensity } \\
(\%)\end{array}$ & $\mathrm{N}$ \\
\hline A & 8,000 & 17.60 & 0.0212 & 22 \\
B & 7,200 & 15.84 & 0.0191 & 22 \\
\hline C & 6,400 & 14.08 & 0.0170 & 22 \\
\hline D & 5,600 & 12.32 & 0.0149 & 22 \\
\hline E & 4,800 & 10.56 & 0.0127 & 22 \\
\hline F & 4,000 & 8.80 & 0.0106 & 22 \\
\hline G & 3,200 & 7.04 & 0.0085 & 22 \\
H & 2,400 & 5.28 & 0.0064 & 22 \\
\hline I & 1,600 & 3.52 & 0.0042 & 22 \\
\hline J & 800 & 1.76 & 0.0021 & 22 \\
\hline
\end{tabular}

$\mathrm{N}=$ number of installed Sus; sampling intensity = sampled area (ha) / 82,918.33 hax 100 . 
Table 2. Characteristics of DBH and wood volume by product (see Material and Methods for product description) in 22 sampling clusters of 8,000- $\mathrm{m}^{2}$ in the Bom Futuro National Forest, Rondônia state, Brazil.

\begin{tabular}{|c|c|c|c|c|c|c|}
\hline Product & N & Variable & Mean \pm SD & Minimum & Maximum & $\begin{array}{l}\text { CV } \\
(\%)\end{array}$ \\
\hline \multirow[b]{2}{*}{ P1 } & \multirow[b]{2}{*}{2,952} & $\mathrm{DBH}(\mathrm{cm})$ & $32.9 \pm 15.1$ & 20.0 & 185.6 & 45.7 \\
\hline & & $\begin{array}{c}\text { Wood } \\
\text { volume }\left(\mathrm{m}^{3}\right)\end{array}$ & $\begin{array}{c}0.925 \pm \\
1.410\end{array}$ & 0.065 & 26.202 & 152.0 \\
\hline \multirow[b]{2}{*}{ P2 } & \multirow{3}{*}{388} & $\mathrm{DBH}(\mathrm{cm})$ & $66.3 \pm 17.5$ & 50.1 & 185.6 & 26.4 \\
\hline & & $\begin{array}{c}\text { Wood } \\
\text { volume }\left(\mathrm{m}^{3}\right)\end{array}$ & $\begin{array}{c}3.502 \pm \\
2.940\end{array}$ & 0.472 & 26.202 & 83.9 \\
\hline & & $\mathrm{DBH}(\mathrm{cm})$ & $70.2 \pm 21.6$ & 50.4 & 148.6 & 30.8 \\
\hline P3 & 40 & $\begin{array}{c}\text { Wood } \\
\text { volume }\left(\mathrm{m}^{3}\right)\end{array}$ & $\begin{array}{c}4.131 \pm \\
3.550\end{array}$ & 1.341 & 19.286 & 86.0 \\
\hline
\end{tabular}

$\mathrm{N}=$ number of sampled trees; $\mathrm{SD}=$ standard deviation; $\mathrm{DBH}=$ diameter at breast height; $\mathrm{CV}=$ coefficient of variation

$$
\begin{aligned}
& \left(E_{\alpha}\right)=t s_{x} / \sqrt{ } n \\
& \left(E_{r}\right)=100 E_{\alpha} / \bar{x}
\end{aligned}
$$

Equation [2]

Equation [3]

where: $s_{x}$ the standard deviation of the MV; $n$ is the number of SUs; and $t$ is the Student's t-test value.

Scenarios exhibiting a decrease of up to five percentage points in precision in $\mathrm{E}_{\mathrm{r}}$ relative to $8,000-\mathrm{m}^{2}$ clusters were considered to display a precision in the MV estimates equivalent to that of the standard SU.

\section{RESULTS}

Mean MV varied from 158.5 to $128.7 \mathrm{~m}^{3} \mathrm{ha}^{-1}$ for $\mathrm{P} 1$, 69.6 to $45.6 \mathrm{~m}^{3} \mathrm{ha}^{-1}$ for P2, and 12.3 to $4.40 \mathrm{~m}^{3} \mathrm{ha}^{-1}$ for P3 (Figure 3). SUs of $4,000 \mathrm{~m}^{2}$ produced the highest means in all products, while SUs of $800 \mathrm{~m}^{2}$ produced the lowest. The means for all products were very similar for SUs with areas $\geq 2,400 \mathrm{~m}^{2}$.

The 95\% CI remained relatively constant with increasing SU area, except for $800-\mathrm{m}^{2}$ SUs, in which the CI was wider, thus the uncertainty greater than for the other scenarios (Figure 3). P3 in $800-\mathrm{m}^{2}$ SUs had a negative lower limit of the CI, which was owed to the low density of trees of commercial value with $\mathrm{DBH} \geq 50 \mathrm{~cm}$ in forest stands, which made them vary scarce in the sampled areas of $800-\mathrm{m}^{2} \mathrm{SUs}$ (Figure 2; Table 1).

MV for P1 and P2 did not differ significantly from scenario A (original SU area of 8,000 for $\mathrm{m}^{2}$ ) for areas $\geq 2,400$ $\mathrm{m}^{2}$ (Table 3). Accordingly, the $95 \% \mathrm{CI}$ tended to be more stable around the mean from 2,400 $\mathrm{m}^{2}$ onwards (Figure 3). For P3, the MV of SU areas of $1,600 \mathrm{~m}^{2}$ or larger did not difer significantly from the original SU area (Table 3).

For P1 and P2, we observed a strong trend towards the stabilization of the Er of the MV in SUs $\geq 1,600 \mathrm{~m}^{2}$ (Figure 4b). The Er for P3 decreased constantly with the increase of SU area, while Ea did not vary noticeably, unlike it did for P1
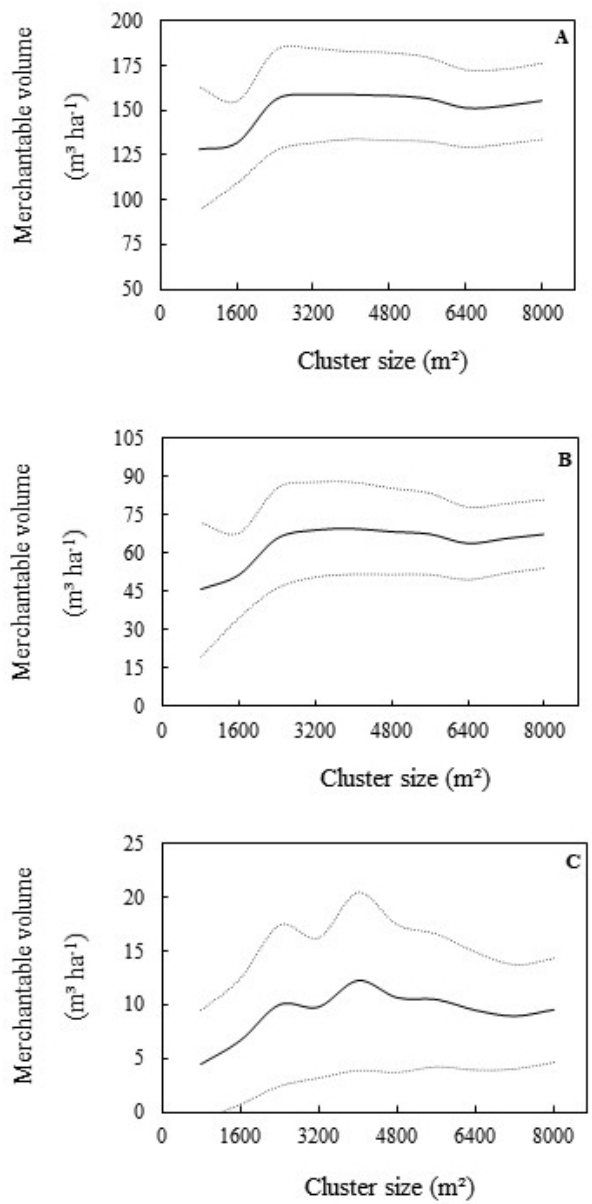

Figure 3. Mean (solid line) and $95 \%$ confidence interval (dotted lines) for the estimation of merchantable wood volume in sampling areas of different size for Product 1 (A), Product 2 (B) and Product 3 (C) in Bom Futuro National Forest, Rondônia, Brazil. Means are based on 22 cluster replicates.

and P2 between 800 and 1,600 $\mathrm{m}^{2}$ (Figure 4a). The product with the highest Ea presented the lowest Er and vice-versa (Figure 4a).

Adopting a SU of $2,400 \mathrm{~m}^{2}$ to estimate $\mathrm{P} 1$ resulted in a precision loss of $4.4 \%$ relative to the $8,000-\mathrm{m}^{2} \mathrm{SU}$ ( $E r$ increased from $13.9 \%$ to $18.3 \%$, Figure $4 \mathrm{~b}$ ). For P2, using a $\mathrm{SU}$ of $4,800 \mathrm{~m}^{2}$ resulted in an error increase from $19.9 \%$ to $24.5 \%$ ( $4.6 \%$ increase, Figure $4 \mathrm{~b})$. The precision was reduced in $3.4 \%$ when using a SU of $7,200 \mathrm{~m}^{2}$ for $\mathrm{P} 3\left(E_{r}\right.$ increased from $50.6 \%$ to $54 \%$, Figure $4 \mathrm{~b}$ ).

The relationship between $\mathrm{CV}$ and SU area followed a negative exponential trend for the three products (Figure 5). The CV is linked to the abundance of each product in the sampled area, thus the largest variation range was observed for the least abundant product (P3) (120 to 260\%), while P2 had the intermediate range (50 to $130 \%$ ), and $\mathrm{P} 1$, being the most abundant product, exhibited the smallest range (34 to 64\%). As P2 is less abundant than P1, its CV was 1.5 to 2.5 

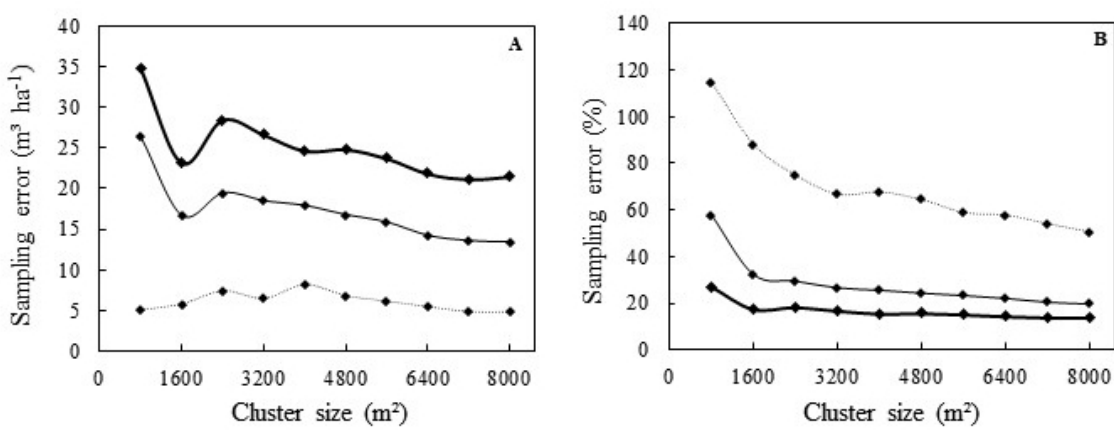

$\longrightarrow$ Product 1

$\rightarrow$ Product 2

- Product 3

Figure 4. Relationship between cluster size and absolute sampling error (A) and relative sampling error (B) of merchantable wood volume estimates in sampling areas of different size for Product 1, Product 2, and Product 3 in Bom Futuro National Forest, Rondônia, Brazil. Points are the mean of 22 replicates.
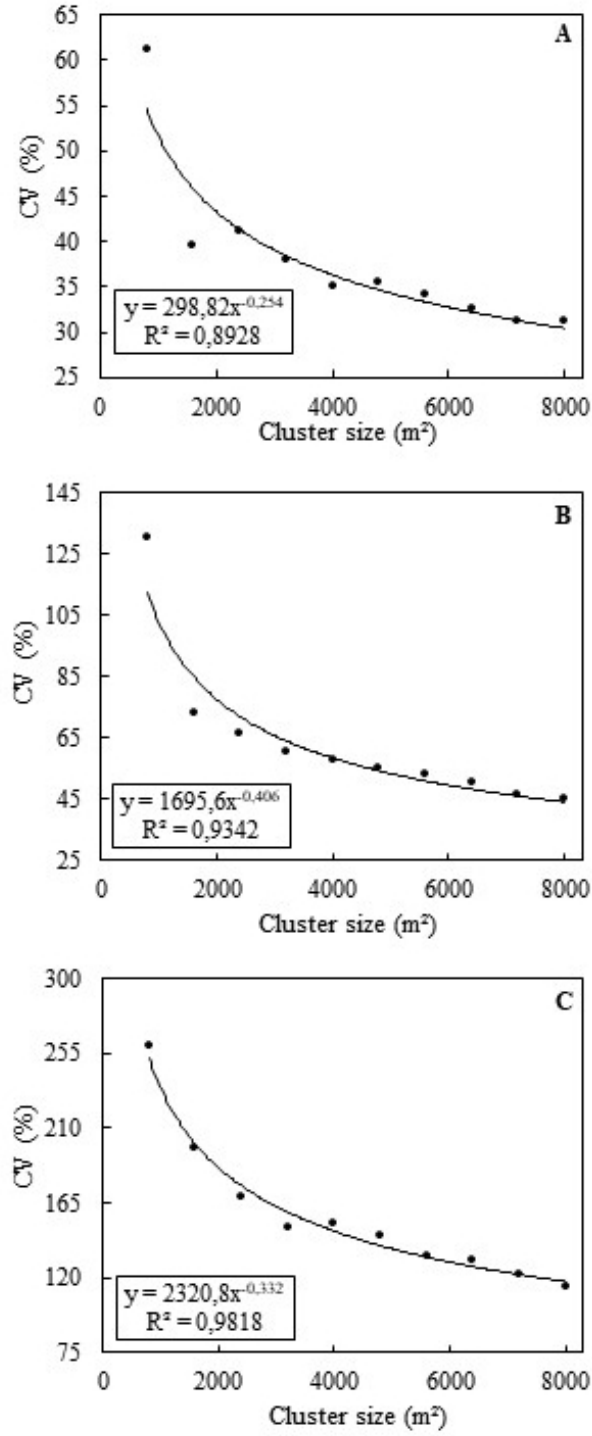

Figure 5. Relationship between cluster size and coefficient of variation of merchantable wood volume estimates in sampling areas of different size for Product 1 (A), Product 2 (B) and Product 3 (C) in Bom Futuro National Forest, Rondônia, Brazil. Points are the mean of 22 replicates.
Table 3. T-test values for comparison of mean merchantable wood volume $\left(\mathrm{m}^{3}\right.$ ha-1) $^{-1}$ estimated for a standard cluster size of $8,000 \mathrm{~m}^{2}$ with nine levels of cluster-size reduction for Product 1, Product 2 and Product 3 (see Material and Methods) in Bom Futuro National Forest, Rondônia, Brazil. P-values in bold indicate statistically significant comparisons.

\begin{tabular}{lcccccc}
\hline \multirow{2}{*}{ Comparison } & \multicolumn{2}{c}{ Product 1 } & \multicolumn{2}{c}{ Product 2 } & \multicolumn{2}{c}{ Product 3 } \\
\cline { 2 - 7 } & t-test & $p$-value & t-test & $p$-value & t-test & $p$-value \\
\hline $8,000 \mathrm{~m}^{2} \times 7,200 \mathrm{~m}^{2}$ & 0.284 & 0.7791 & 0.266 & 0.793 & 0.260 & 0.7973 \\
$8,000 \mathrm{~m}^{2} \times 6,400 \mathrm{~m}^{2}$ & 0.381 & 0.7068 & 0.555 & 0.585 & 0.027 & 0.9788 \\
$8,000 \mathrm{~m}^{2} \times 5,600 \mathrm{~m}^{2}$ & -0.115 & 0.9092 & -0.014 & 0.989 & -0.412 & 0.6845 \\
$8,000 \mathrm{~m}^{2} \times 4,800 \mathrm{~m}^{2}$ & -0.266 & 0.7928 & -0.159 & 0.875 & -0.484 & 0.6335 \\
$8,000 \mathrm{~m}^{2} \times 4,000 \mathrm{~m}^{2}$ & -0.321 & 0.7515 & -0.345 & 0.734 & -1.179 & 0.2514 \\
$8,000 \mathrm{~m}^{2} \times 3,200 \mathrm{~m}^{2}$ & -0.312 & 0.7579 & -0.261 & 0.797 & -0.103 & 0.9192 \\
$8,000 \mathrm{~m}^{2} \times 2,400 \mathrm{~m}^{2}$ & -0.049 & 0.9610 & 0.256 & 0.800 & -0.201 & 0.8429 \\
$8,000 \mathrm{~m}^{2} \times 1,600 \mathrm{~m}^{2}$ & 2.212 & $\mathbf{0 . 0 3 8 2}$ & 2.494 & $\mathbf{0 . 0 2 1}$ & 1.257 & 0.2224 \\
$8,000 \mathrm{~m}^{2} \times 800 \mathrm{~m}^{2}$ & 2.557 & $\mathbf{0 . 0 1 8 4}$ & 3.384 & $\mathbf{0 . 0 0 3}$ & $\mathbf{2 . 2 1 1}$ & $\mathbf{0 . 0 3 8 2}$ \\
\hline
\end{tabular}

times higher than that of P1. Likewise, P3 exhibited a CV two to three times higher than that of $\mathrm{P} 2$.

\section{DISCUSSION}

\section{Minimum sampling-unit size}

Our objective was to determine the minimum SU size that estimates the MV as accurately and precisely as the $8,000-\mathrm{m}^{2}$ standard SU in an area of Amazon rainforest, which resulted to be 2,400 $\mathrm{m}^{2}$ for $\mathrm{P} 1,4,800 \mathrm{~m}^{2}$ for P2, and 7,200 $\mathrm{m}^{2}$ for P3.

Considering accuracy as the only criterion to choose the minimum SU size, an area of $2,400 \mathrm{~m}^{2}$ would be suitable for all products. However, given the observed variation in precision, additional caution is needed in the assessment of minimum SU size. Sampling errors directly affect the confidence interval of an estimate. The larger the error in an estimate, the wider the confidence interval, and viceversa (Loetsch et al. 1973; Péllico Netto and Brena 1997). Although $E_{r}$ and $E_{a}$ are complementary to each other, $E_{r}$ has greater applicability in practical terms (Cavalcanti et al. 2009; 
Cavalcanti et al. 2011; Oliveira et al. 2014). Specifically, $E_{a}$ lacks information about the magnitude of its value relative to the mean. For example, an absolute error of $20 \mathrm{~m}^{3} \mathrm{ha}^{-1}$ for a mean of $40 \mathrm{~m}^{3} \mathrm{ha}^{-1}$ corresponds to a relative error of $50 \%$, which is considered high in forest inventories. Conversely, for this same absolute error, but with a mean of $200 \mathrm{~m}^{3} \mathrm{ha}^{-1}$, the relative error would be only $10 \%$, which is acceptable for most inventories.

In a similar study in an area of Amazon forest in Pará state, Flores et al. (2012) evaluated the effect of distance between clusters and among sub-plots within clusters on three products based on total wood volume of trees with $\mathrm{DBH}$ $\geq 30 \mathrm{~cm}$ (77 forestry species, ten most abundant species, and ten most commercialized species), and concluded that the $8,000-\mathrm{m}^{2}$ cluster is efficient in estimating the analyzed products. Likewise, Queiroz et al. (2011) also concluded that a 8,000- $\mathrm{m}^{2}$ Maltese-cross cluster was efficient in estimating three wood-volume products $(\mathrm{DBH} \geq 25 \mathrm{~cm})$ in the Tapajós Natinal Forest, also in Pará state (all species, species with an international market, and only Manilkara huberi (Ducke) Standl). Our study showed that it is possible to reduce the SU area while attaining similar accuracy and precision as with an $8,000-\mathrm{m}^{2}$ cluster, allowing to reduce inventory costs while obtaining reliable MV estimates.

The recommendations of a larger SU by Queiroz et al. (2011) and Flores et al. (2012) is due to their use of the maximum curvature method to obtain the minimum SU size, which is a method based on the stabilization of the coefficient of variation. Our results also indicate that the coefficients of variation tend to stabilize with $\mathrm{SUs} \sim 8,000 \mathrm{~m}^{2}$, however, we did not aim to determine the SU size that stabilizes the MV estimation by using the maximum curvature method, not to determine where the coefficient of variation stabilizes, since $8,000 \mathrm{~m}^{2}$ was the largest SU area evaluated.

\section{Effect of sampling-unit area on merchantable volume}

Cavalcanti et al. (2009) assessed the effect of SU area on the precision and accuracy of inventories in the Amazon forest through the $\mathrm{MV}$ of trees with $\mathrm{DBH} \geq 40 \mathrm{~cm}$, and noted an exponential decrease in MV variation as SU area increased, which was also observed by Flores et al. (2012) in our study. Cavalcanti et al. (2009) tested SU areas ranging from 2,500 to $20,000 \mathrm{~m}^{2}$ and found that the coefficient of variation tended to stabilize with $S U s \geq 7,500 \mathrm{~m}^{2}$, which was also observed in our study, with a stabilization in the coefficient of variation of P1 at $S U s \geq 7,200 \mathrm{~m}^{2}$.

Flores et al. (2012) found a range of coefficients of variation comparable to our results, with $\sim 100-150 \%$ for the most abundant product, $-130-200 \%$ for intermediate abundance, and $-140-240 \%$ for the less abundant product. Likewise, Queiroz et al. (2011) also observed coefficients of variation ranges of $\sim 100 \%,-100-300 \%$, and $-150-450 \%$, respectively for the most, intermediate, and less abundant products.

Similar to Flores et al. (2012) and Queiroz et al. (2011), we also observed that scarcer products and smaller SUs resulted in larger coefficients of variation. The high coefficients of variation were caused by the high errors observed in P3 and, less intensely, by the errors in P2 and P1. As the abundance of each product varies with the successional stage and disturbance state of the forest, our recommendation applies to forests with products of similar abundance to those evaluated in here.

\section{Sampling intensity and merchantable volume}

The sampling intensity of $0.0212 \%$ adopted in our study for the $8,000-\mathrm{m}^{2}$ cluster sufficed to meet the minimum precision of $20 \%$ for P1 and P2 (see Figure $4 \mathrm{~b}$ ). If more precise estimates are required, a higher sampling intensity would likely be necessary. For example, in the study conducted by Cavalcanti et al. (2011) in an Amazon forest, a sampling intensity of $14 \%(-660 \mathrm{x}$ greater than $0.0212 \%)$ was needed to meet a precision of $-8 \%$ of the MV of commercial species of trees with $\mathrm{DBH} \geq 40 \mathrm{~cm}$. Thus, the sampling intensity adopted in our study may be too low to achieve an error smaller than $10 \%$, especially for scarcer products such as P2 and P3. In a study on the effect of SU size on tree wood and carbon-stock estimates in an Amazonian forest, Oliveira et al. (2014) found best results with $\mathrm{SUs} \geq 1,200 \mathrm{~m}^{2}$ for $\mathrm{DBH} \geq 20 \mathrm{~cm}$, with mean uncertainty of $9.07 \%$, and with SUs between 2,000 $\mathrm{m}^{2}$ and $3,000 \mathrm{~m}^{2}$ for $\mathrm{DBH} \geq 25 \mathrm{~cm}$, with mean uncertainty of $6.37 \%$. These results also corroborate our findings that the increase of SU area increases precisions.

Andrade et al. (2015) also evaluated tree-volume estimates with varying SU area $\left[1,500 \mathrm{~m}^{2}(30 \mathrm{~m} \times 50 \mathrm{~m})\right.$ for $\mathrm{DBH}$ $10-25 \mathrm{~cm}, 3,000 \mathrm{~m}^{2}(30 \mathrm{~m} \times 100 \mathrm{~m})$ for DBH $25-50 \mathrm{~cm}$, and $7,500 \mathrm{~m}^{2}(30 \mathrm{~m} \times 250 \mathrm{~m})$ for $\mathrm{DBH} \geq 50 \mathrm{~cm}$ ] and obtained an error smaller than $10 \%$ for the volume of trees with $\mathrm{DBH}$ $\geq 10 \mathrm{~cm}$ and trees with $\mathrm{DBH} \geq 50 \mathrm{~cm}$. This accuracy was considerably higher than that observed in our study, which may be due to the higher sampling intensity $(-10$ times higher) in the study by Andrade et al. (2015) and shows that sampling intensity is directly related to inventory accuracy. Since the intensity depends on the area and number of SUs, it is expected that more SUs will contribute to improve the accuracy.

We evaluated the effect of SU area while keeping SU number fixed. An alternative approach would be to assess $S U$ area reduction and to vary the number of SUs (e.g., Kauai et al. 2019). Varying SU area usually has a different effect than varying number of SUs (Oliveira et al. 2014). For example, in forest remnants of an ombrophilous forest in southern Brazil, gains in precision on the basal area estimation were less evident when varying SU area than when varying number of Sus (Augustynczik et al. 2013). Future studies should address 
both number of SUs and SU area, as well as other variables of interest, to improve our ability to increase the efficiency of forest inventories.

\section{CONCLUSIONS}

Our results indicate that smaller clusters could replace the original standard $8,000-\mathrm{m}^{2}$ cluster for forest inventory estimates in Amazon rainforest without losing precision and accuracy of merchantable volume estimation. We found that the minimum sampling unit size to estimate merchantable volume is $2,400 \mathrm{~m}^{2}$ for trees with $\mathrm{DBH} \geq 20 \mathrm{~cm}, 4,800 \mathrm{~m}^{2}$ for trees with $\mathrm{DBH} \geq 50 \mathrm{~cm}$, and 7,200 $\mathrm{m}^{2}$ for commercial species with $\mathrm{DBH} \geq 50 \mathrm{~cm}$ and stem quality of level 1 or 2 . The precision of the estimates was affected more strongly by reduction of cluster size than accuracy. Regardless of the wood product abundance in the forest, a cluster size of $2,400 \mathrm{~m}^{2}$ yielded estimates as accurate as those of the original standard cluster of $8,000 \mathrm{~m}^{2}$. Precision, however, was dependent on cluster size and product abundance. We encourage other researchers to further assess the relationship between cluster size and accuracy and precision of other variables of interest of the Brazilian NFI, focusing on determining smaller yet reliable cluster sizes for wood product estimates.

\section{ACKNOWLEDGMENTS}

We are thankful to Instituto Brasileiro do Meio Ambiente e dos Recursos Naturais Renováveis (IBAMA) for providing the data necessary for this research.

\section{REFERENCES}

Alvares, C.A.; Stape, J.L.; Sentelhas, P.C.; Gonçalves, J.L.M.; Sparovek, G. 2013. Köppen's climate classification map for Brazil. Meteorologische Zeitschrift, 22: 711-728.

Andrade, D.F.; Gama, J.R.V.; Melo, L.O; Ruschel, A.R. 2015. Inventário florestal de grandes áreas na Floresta Nacional do Tapajós, Pará, Amazônia, Brasil. Biota Amazônia, 5: 109-115.

Augustynczik, A.L.D.; Machado, S.A.; Figueiredo Filho, A.; Péllico Netto, S. 2013. Avaliação do tamanho de parcelas e de intensidade de amostragem em inventários florestais. Scientia Forestalis, 41: 361-368.

Cavalcanti, F. J. B.; Machado, S.D.A.; Hosokawa, R.T. 2009. Tamanho de unidade de amostra e intensidade amostral para espécies comerciais da Amazônia. Floresta, 39: 207-214.

Cavalcanti, F.J.B; Machado, S.A.; Osokawa, R.T.; Cunha, U.S. 2011. Comparação dos valores estimados por amostragem na caracterização da estrutura de uma área de floresta na Amazônia com as informações registradas no censo florestal. Revista Árvore, 35: 1061-1068.

Cochran, W.G. 1977. Sampling Techniques. 3rd ed. John Wiley \& Sons, New York, 448p.

Druszcz, J.P.; Nakajima, N.Y.; Péllico Netto, S.; Machado, S.A. 2012. Custos de inventário florestal com amostragem de Bitterlich
(PNA) e conglomerado em cruz (CC) em plantação de Pinus taeda L. Scientia Forestalis, 40: 231-239.

Flores, O.M.M.; Queiroz, W.T.; Pinheiro, J.G.; Oliveira, F.A.; Moraes, A.; Valente, M. D.R. 2012. Comparação de tamanhos e distâncias de subparcelas aplicadas em processo de amostragem por conglomerado. Acta Amazonica, 42: 345-354.

Gregoire, T.G.; Valentine, H.T. 2007. Sampling strategies for natural resources and the environment. Chapman and Hall/CRC, New York, 494p.

ICMBio. 2019. Plano de manejo da Floresta Nacional do Bom Futuro (Flona do Bom Futuro), RO. Instituto Chico Mendes de Conservação da Biodiversidade. (https://www.icmbio.gov. $\mathrm{br} /$ portal/unidadesdeconservacao/biomasbrasileiros/amazonia/ unidades-de-conservacao-amazonia/1924-flona-bom-futuro). Accessed on 21 Sep 2020.

Kauai, F.; Corte, A.P.D.; Cysneiros, V.; Pelissari, A.L.; Sanquetta, C.R. 2019. Evaluation of forest inventory processes in a forest under concession in the southwestern Brazilian Amazon. Acta Amazonica, 49: 91-96.

Lawrence, M.; McRoberts, R.E.; Tomppo, E.; Gschwantner, Th.; Gabler, K. 2010. Comparisons of National Forest Inventories. In: Tomppo, E.; Gschwantner, Th.; Lawrence, M.; McRoberts, R.E. (Ed.). National Forest Inventories. Springer Netherlands, Dodrecht, p.19-32.

Loetsch, F.; Zohrer, F.; Haller, K. 1973. Forest Inventory. 2nd ed. BLV Verlagsgesellchaft, München, 469p.

MMA. 2004. Mapa de cobertura vegetal: Amazônia. Ministério do Meio Ambiente, Brazil. (http://mapas.mma.gov.br/geodados/ brasil/vegetacao/vegetacao2002/amazonia/documentos/ relatorio_final.pdf). Accessed on 21 Sep 2020.

Oliveira, M.M.; Higuchi, N.; Celes, C.H.; Higuchi, F.G. 2014. Tamanho e formas de parcelas para inventários florestais de espécies arbóreas na Amazônia central. Ciência Florestal, 24: 645-653.

Péllico Netto, S.; Brena, D.A. 1997. Inventário Florestal. 1st ed. UFPR, Curitiba, 316p.

Queiroz, W.T.; Péllico Netto, S.; Valente, M.D.R.; Pinheiro, J.G. 2011. Análise estrutural da unidade conglomerada cruz de malta na Floresta Nacional do Tapajós, estado do Pará, Brasil. Floresta, 41: 9-18.

Räty, M.; Heikkinen, J.; Kangas, A. 2018. Assessment of sampling strategies utilizing auxiliary information in large-scale forest inventory. Canadian Journal of Forest Research, 48: 749-757.

SFB. 2014. Manual de Campo: Procedimentos para coleta de dados biofísicos e socioambientais, Serviço Florestal Brasileiro. (http://www.florestal.gov.br/documentos/informacoesflorestais/ inventr o-florestal-nacional-ifn/documentos/manual-de-campoifn/3028-manual-de-campo/file). Accessed on 20 Mar 2020.

SFB. 2019. Inventário florestal nacional - metodologia, Serviço Florestal Brasileiro. (https://www.florestal.gov.br/metodologia). Accessed on 25 Mar 2021.

SFB. 2020. Inventário florestal nacional, Serviço Florestal Brasileiro. (https://www.florestal.gov.br/o-que-e-o-ifn). Accessed on 25 Mar 2021. 
Tomppo, E.; Gschwantner, Th.; Lawrence, M.; McRoberts, R.E. 2010. National Forest Inventories. Springer Netherlands, Dodrecht, 612p.

Vibrans, A.C.; Sevgnani, L.; Lingner, D.V.; Gasper, A.L.; Sabbagh, S. 2010. Inventário florístico florestal de Santa Catarina (IFFSC): aspectos metodológicos e operacionais. Pesquisa Florestal Brasileira, 330: 291-302.

Westfall, J.A.; Lister, A.J.; Scott, C.T. 2016. Precision and cost considerations for two-stage sampling in a panelized forest inventory design. Environmental Monitoring and Assessment, 188: 11. doi: 10.1007/s10661-015-5002-8

Westfall, J.A.; Lister, A.J.; Scott, C.T.; Weber, T. 2019. Double sampling for post-stratification in forest inventory. European Journal of Forest Research, 138: 375-382.

Westfall, J.A.; Patterson, P.L.; Coulston, J.W. 2011. Post-stratified estimation: within-strata and total sample area recommendations. Canadian Journal of Forest Research, 41: 1130-1139.

WIKIPARQUES. 2019. Floresta Nacional do Bom Futuro. (https:// www.wikiparques.org/wiki/Floresta_Nacional_de_Bom_ Futuro). Accessed on 12 Jan 2020.

RECEIVED: $20 / 07 / 2020$

ACCEPTED: 08/03/2021

ASSOCIATE EDITOR: Angelo Rita 